\title{
Молекулярно-генетичні механізми патогенезу злоякісних пухлин щитоподібної залози (частина 2)
}

\section{Б.Б. Гуда,}

В.М. Пушкарьов,

А.Є. Коваленко,

B.В. Пушкарьов,

О.І. Ковзун,

М.Д. Тронько

ДУ «Інститут ендокринології та обміну речовин ім. В.П. Комісаренка НАМН України»

Резюме. У частині 2 огляду аналізуються нові дані щодо патогенезу медулярного та анапластичного раку — найагресивніших типів злоякісних пухлин щитоподібної залози. Значна увага приділяється механізмам епітеліально-мезенхімального переходу та утворення метастазів, ролі мікрооточення пухлин і запальних процесів у патогенезі. Зроблено також акцент на епігенетичних змінах, які призводять до виникнення та прогресування пухлин щитоподібної залози, зокрема метилюванні ДНК і гістонів, експресії мікроРНК.

Ключові слова: щитоподібна залоза, медулярний рак, анапластичний рак, метилювання, мікроРНК.

\section{Медулярна карцинома (МТС)}

Родинні випадки РТC, FTC та АТС трапляються зрідка, лише в 5\% пацієнтів (переважно в пацієнтів із РТС). МТС, навпаки, успадковується як автосомно-домінантна ознака у $25 \%$ хворих, тоді як близько 75\% випадків МТС є спорадичними [1].

У випадках спадкової МТС можуть бути задіяними інші органи (прищитоподібні та надниркові залози), що спричиняє синдром множинної

\footnotetext{
* Адреса для листування (Correspondence): ДУ «Інститут ендокринології та обміну речовин ім. В.П. Комісаренка НАМН України», вул. Вишгородська, 69, м. Київ, 04114 Україна. E-mail: pushkarev.vm@gmail.com

(С) Б.Б. Гуда, В.М. Пушкарьов, А.Є. Коваленко, В.В. Пушкарьов, О.І. Ковзун, М.Д. Тронько
}

ендокринної неоплазії 2-го типу (MEN2), який поділяється на три підтипи відповідно до фенотипу - MEN2A, MEN2B і родинна медулярна карцинома Щ3 (FMTC). MEN2A характеризується зв'язком МТС із феохромоцитомою або аденомами прищитоподібної залози. Iз MEN2B пов'язано лише феохромоцитому, але синдром характеризується наявністю слизових невром і типовим марфаноїдним габітусом. На відміну від цього, FMTC характеризується лише МТC і відсутністю зв'язків з іншими ендокринними пухлинами або неендокринними проявами $[2,3]$.

Проведено багато досліджень, аби з'ясувати генетичні зміни, пов'язані з патогенезом раку 


\section{Огляди}

щитоподібної залози (ЩЗ). 3 усіх генів, що відіграють роль у пухлинних процесах ЩЗ, найчастіше виявляється протонокоген RET, оскільки він бере участь у розвитку і РTC, і МТC, які за ембріональним походженням є різними пухлинами. RET характеризується різними механізмами дії в цих двох гістотипах. У РТС ген зазвичай активується через перегрупування хромосом (RET/PTC), тоді як у МТС активація визначається зародковою лінією або соматичними мутаціями [3].

Медулярний тиреоїдний рак, на відміну від попередніх типів карцином, розвивається 3 парафолікулярних С-клітин, що секретують кальцитонін, і становить 3-12\% від усіх видів раку Щ3 [4]. Гістологічними особливостями цього виду карциноми є наявність трабекул, папіл. Трапляється в спорадичній або родинній формах (75-80\% і 20-25\% відповідно) і е властивим для MEN2A, MEN2B і родинної не-MEN MTC (FMTC). Причини його виникнення на генетичному рівні менше досліджено, ніж такі FTC і PTC. Точкові зародкові мутації в гені $R E T$ (хромосома 10q11.2) ідентифіковано в більшості пацієнтів із MEN2A, MEN2B, і вони вважаються первинною генетичною причиною хвороби. Соматичні мутації в гені $R E T$ відзначали в 40-50\% спорадичних MTC [5]. Дослідження мутацій у ДНК мітохондрій показало, що для FMTC/MEN2 характерним є високий відсоток трансверсивних мутацій - 81,5\% проти 18,5\% у спорадичних МТС. Мутації змінюють дихальну функцію мітохондрій [5]. Припускається, що мутації мтДНК можуть бути залученими до малігнізації тканини ЩЗ. Нещодавно показано, що додатковим чинником канцерогенезу на тлі мутованого RET можуть бути соматичні мутації в гені, що кодує $\mathrm{P} 18^{\mathrm{INK} 4 \mathrm{C}}$, один із важливих супресорів клітинного циклу. Такі мутації пригнічують функцію та знижують стабільність цього супресора й можуть провокувати розвиток МТC [6].

Прогноз для медулярної карциноми ЩЗ є менш сприятливим, ніж для папілярної та фолікулярної, а рецидиви та застарілі форми МТС практично не піддаються лікуванню.

\section{Анапластичний рак (АTC)}

Понад 90\% диференційованих пухлин Щ3 характеризуються сприятливим прогнозом. I навпаки, рідкісні форми раку - медулярний рак із парафолікулярних С-клітин, карцинома 3 клітин Гюртле, лімфома ЩЗ, карцинома зі сквамозних клітин i, надто, анапластичний рак характеризуються значно гіршими прогнозом і відсотком виживання [7,8].

Анапластичний (низькодиференційований) рак ЩЗ має солідну будову. Становить близько 1-5\% від усіх злоякісних новоутворень Щ3, натомість є причиною понад 50\% смертей від усіх видів раку ЩЗ. Прогноз захворювання є вкрай несприятливим [9]. Медіана виживання становить 4 місяці (цей показник не поліпшується впродовж останніх 50 років) унаслідок неконтрольованого системного метастазування [10].

На відміну від клітин диференційованого раку Щ3 (РTC і FTC), клітини ATC не зберігають жодних біологічних особливостей або функцій нормальних фолікулярних клітин, таких як поглинання йоду, синтез тиреоглобулінів і залежність від ТТГ [11].

АТC часто походить зі ЩЗ із відхиленнями від норми. Так, хронічний зоб зареєстровано в понад 80\% пацієнтів, а в деяких пацієнтів виявили DTC, пов'язаний з АTC [11]. Хронічний автоімунний тиреоїдит (AIT) також часто супроводжується злоякісним перетворенням тканини Щ3 [12]. Прогресію до АТС зв'язували з багатостадійним процесом дедиференціювання, який починається 3 попереднього генезу DTC (рис.). Ця гіпотеза підтверджується тим, що мутації B-Raf i Ras, що трапляються приблизно в $60 \%$ і $12 \%$ РТC відповідно, виявляються з більшою частотою в АTC, які містять ділянки DTC $[13,14]$. Тому

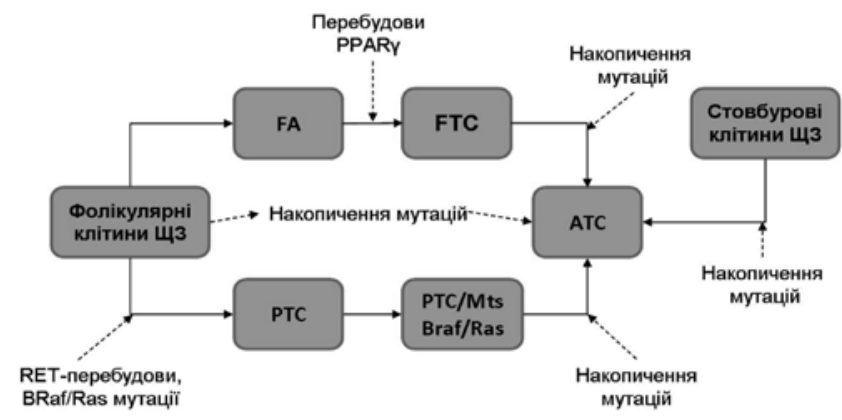

Рис. Основні гіпотези щодо походження АТС [8]: пряма малігнізація фолікулярних клітин щитоподібної залози (найменш імовірний сценарій, зумовлений низькою проліферативною активністю тиреоцитів); подальша дедиференціація DTC (PTC і FTC), що несуть BRAF i RAS мутації, але без перебудов RET/PTC і PAX8/PPARү; трансформація стовбурових клітин у ракові стовбурові клітини, що дають початок АTC. 
процес дедиференціації може бути зумовлений ступінчастим накопиченням соматичних мутацій у генах, пов'язаних із канцерогенезом, зокрема в TP53 і генах, що кодують чинники сигнального шляху PI3K/Akt [15]. Проте наявність чистих випадків АТС свідчить про можливість прямої трансформації нормальної фолікулярної клітини в цілком недиференційовану ракову клітину [11].

У багатоступінчастому канцерогенезі клітини АТС генеруються безпосередньо 3 тиреоцитів через різноманітні пошкодження їх геномів і набуття здатності до необмеженої проліферації, інвазії та метастазування. Але оскільки тиреоцити зрідка діляться в дорослих, здається малоймовірним, що після кількох поділів вони набувають усіх цих злоякісних ознак. Головною проблемою класичної моделі багатоступінчастого канцерогенезу $\mathrm{\epsilon}$ те, що анапластичні карциноми, що описуються як похідні від диференційованих карцином за рахунок накопичення мутацій, не містять генетичних змін, які часто спостерігаються в DTC. Перебудови $R E T / \mathrm{PTC}$ і PAX8/PPAR $\gamma$ спостерігаються з високою частотою в DTC, але не виявляються в АТС [16].

Модель раку, пов'язана зі стовбуровими клітинами (CSC - cancer stem cells), припускає, що невелика кількість клітин у пухлині є відповідальними за стійкість до променевої та хіміотерапії, а також за перебіг хвороби з рецидивами та метастазами. Така модель, що може пояснити агресивну поведінку деяких видів раку ЩЗ, розвиток рецидивів раку та метастазів після операції, а також стійкість деяких видів раку Щ3 до терапії, передбачає участь CSC [17, 18]. Це узгоджується з моделлю канцерогенезу ЩЗ із фетальних клітин, яка припускає, що стовбурові клітини дають початок безпосередньо як добре диференційованим, так і недиференційованим карциномам Щ3 (рис.) [16].

АТС можна розділити на три молекулярні групи: B-Raf, Ras i пухлини з рецидивуючими мутаціями в генах $N F 1, M T O R$ та в родині MutL-гомологічних генів, відповідальних за репарацію помилково спарених основ ДНК, що призводить до гіпермутаційного фенотипу [19].

Мутації B-Raf V600E i Ras залишаються основними онкогенними чинниками агресивної карциноми ЩЗ, але в АТС відзначено додаткові мутації.
Мутації ТР53 (до 59\%), промотора TERT (зворотна транскриптаза теломерази) (до 73\%), EIF1AX (X-linked eukaryotic translation initiation factor $1 \mathrm{~A})$, а також зміни в сигнальному шляху PIK3CA/Akt/mTOR (PIK3CA, PTEN, PIK3C2G, PIK3CG, PIK3C3, PIK3R1, PIK3R2, Akt3, TSC1, TSC2, mTOR), комплексі ремоделювання нуклеосом SWISNF (ARID1A, ARID1B, ARID2, ARID5B, $S M A R C B 1, P B R M 1, A T R X)$, генів репарації ДНК (MSH2, MSH6, MLH1) і гістонових метилтрансфераз (KMT2A, KMT2C, KMT2D, SETD2) присутні з більшою частотою в недиференційованих карциномах Щ3 [20]. EIF1AX - ген, пов'язаний 3 евкаріотичними чинниками ініціації трансляції, асоціюється з прогресуванням від FTC до АТC, оскільки мутації EIF1AX тісно пов'язано з мутаціями Ras. Мутації в сигнальному шляху WNT, що включають $C T N N B 1$ ( $\beta$-катенін), $A P C$ та AXIN1, трапляються в АТС із меншою частотою - від $3 \%$ до $4,5 \%$. $\beta$-катенін відіграє в клітині подвійну роль. 3 одного боку, він бере участь у формуванні міжклітинних контактів, з іншого - залучений до регуляції клітинної проліферації та інвазійних процесів через трансактивацію різних генів, таких як с-Mус, цикліну D1, фібронектину та генів металопротеїназ $[19,21]$.

В АТС ідентифіковано також нові молекулярні зміни, такі як мутації в гені, що кодує ізоцитратдегідрогеназу-1 (IDH1), і двоточкові мутації в гені $A L K$, Leu1198Phe (c.3592C > T) i Gly1201Glu (c.3602G>A) [11]. Проте їх роль у канцерогенезі АТС наразі не з'ясовано.

Встановлено, що в досліджених пухлинах присутні 16 генів, пов'язаних із раком, які зазвичай не визнаються як фактори, що визначають злоякісні новоутворення ЩЗ. Деякі із цих мутацій присутні в багатьох зразках і сильно корелюють із нетиреоїдними злоякісними новоутвореннями - NF1, mTOR, ERBB2, DAXX, MLL2 i NOTCH2 [19].

Такі генетичні зміни, як CNA (copy number alternations), є звичайними та поширеними в розвинених карциномах ЩЗ, надто в АТС. Більшість CNA пов'язано зі специфічними типами пухлин і різними мутаціями генів канцерогенезу [21].

Спостерігалось також зниження експресії гена CBX7, продукт якого відіграє ще не визначену роль у трансформації ЩЗ. Характерно, що 
Огляди

зниження його експресії було пропорційним ступеню малігнізації тканини, і мав місце градієнт від фолікулярної аденоми до анапластичного раку. У післячорнобильських пухлинах відзначено кореляцію між делеціями в хромосомі 22q13.1, де розташовано ген СВX7, і погіршенням прогнозу захворювання [22].

Аналіз експресії генів матричними методами в недиференційованих карциномах ЩЗ показав активацію генів, пов'язаних із МАРКсигнальним шляхом, TGF- $\beta$-каскадом, клітинним циклом, полімеризацією актину, фокальною адгезією та рухливістю клітин [23]. Автори надто відзначали активацію матриксних металопротеїназ і сімейства генів колагену.

Лікування АТС, згідно з останніми рекомендаціями Американської тиреоїдної асоціації, передбачає оперативне втручання, променеву та хіміотерапію [11, 24, 25]. В АТС відбувається активація мітогенних та ангіогенних сигнальних шляхів, і передклінічні дослідження показали, що пригнічення ключових кіназ у цих шляхах може справляти протипухлинний ефект [26-29]. Отже, крім традиційних методів лікування, певні перспективи має нова молекулярно-таргетна терапія. Такі препарати часто є інгібіторами рецепторних тирозинкіназ, і деякі з них протестовано в клінічних випробуваннях II та III фаз із демонстрацією досить обнадійливих результатів [30]. Але наразі уніфікованого лікування АТС, що поліпшувало б загальне виживання, не існує.

Епітеліально-мезенхімальний перехід і метастази пухлин щитоподібної залози

$\boldsymbol{E M T}$ і метастази. ЕМТ було вперше визначено як процес диференціації на початку ембріогенного морфогенезу. Це скоординований молекулярний і клітинний процес зниження клітинної адгезії, апікально-базолатеральної полярності, епітеліальних маркерів і надбання мобільності, веретеноподібної форми клітин і мезенхімальних маркерів [31]. Процес ЕМТ вказує на потенційний механізм, який посилює відділення ракових клітин від первинних пухлин [31]. Крім того, TGF- $\beta-$, RTK/Ras-, Wnt-, Notch-, Hedgehog- і NF-кB-залежні сигнальні шляхи та автокринні чинники беруть участь у процесі EMT [32]. Трансформуючий чинник росту h (TGF-h), члени родини епідермального чинника росту (EGF), чинники росту фібробластів (FGF), чинник росту гепато- цитів (HGF) і інсуліноподібний чинник росту (IGF) можуть індукувати ЕMT автокринним або паракринним шляхом [32]. Крім того, мікроРНК-200 відіграє ключову роль в EGF/ EGFR-опосередкованій інвазії клітин ЩЗ і в EMT in vitro [33].

Е-кадгерин, один із контролерів епітеліального фенотипу, також бере участь в ЕMT. Знижувальну регуляцію Е-кадгерину продемонстровано на тлі ЕMT та утворення метастазів. Метилювання ДНК промотора гена Е-кадгерину, $C D H 1$, змінюється на різних стадіях метастатичного процесу [34]. Доведено, що ЕМТ відіграє важливу роль у міграції ракових клітин Щ3. Рівень експресії Е-кадгерину може бути пов'язаний із дедиференціюванням, прогресією та метастазуванням карцином ЩЗ. Експресія Е-кадгерину є значно нижчою в РТС із метастазами в лімфатичних вузлах, ніж без таких. Припускають, що експресія гена та посттранскрипційний контроль рівня Е-кадгерину можуть бути порушеними в пухлинах Щ3 людини. Віментин, мезенхімальний клітинний маркер, часто надекспресовано в метастатичних РТС [34]. Отже, тісна перехресна взаємодія між онкоген-активованими сигнальними шляхами та ЕMT-пов'язаними механізмами зумовлює агресивність і метастазування раку Щ3.

Регресійний аналіз підтверджує наявність сильного зв'язку між CXCR4, B-Raf і ступенем неопластичної інфільтрації. Одержані дані чітко вказують, що експресія рецептора хемокіну, індукована онкогенною активацією, є основною детермінантою локального поширення пухлинних клітин. Ці спостереження відповідають результатам праць, які демонструють зв'язок між мутацією B-Raf та інвазійністю пухлини. Дані вказують на те, що експресія CXCR4 і статус мутації B-Raf можуть провокувати агресивніший фенотип PTC, зокрема посилювати поширення пухлини за межі Щ3 [35].

Агресивність карцином ЩЗ корелює з посиленим ангіогенезом, а також експресією рецепторів: VEGF - VEGFR, чинника росту тромбоцитів (PDGF) - PDGFR, FGF - FGFR, EGF - EGFR i HGF - c-Met (що стимулює або інгібує ангіогенез) [36]. VEGF і його основний рецептор VEGFR-2 надекспресуються в DTC і залучені до посилення агресивності та про- 
гресування пухлини. Розробка препаратів, які мають своїми мішенями VEGF, є перспективним терапевтичним підходом до лікування раку Щ3 [37].

Супресори метастазування пухлин ЩЗ. Гени-супресори кодують білки, які пригнічують метастазування, не впливаючи на злоякісну трансформацію тканини. Показано, що експресію супресорів метастазування пригнічено в метастатичних пухлинних клітинах порівняно $з$ такою в онкогенних, але не метастатичних пухлинних клітинах. Ідентифіковано понад двадцять генів-супресорів [38]. Визначення механізмів утворення метастатичних супресорів може мати потенційне терапевтичне значення.

Ідентифіковано цілу низку генів, які кодують чинники, що пригнічують метастази, у тому числі NM23, CAD1, MKK4, KAI-1 (CD82), TXNP, CRSP3, BRMS1, KiSS-1 тощо. Деякі із цих генів досліджено в пухлинах Щ3 - NM23, CAD1, KAI-1, KiSS-1, GPR54 i $R C A N 1-4$. Інвазійні та метастатичні пухлини характеризуються зниженою регуляцією NM23, CAD1 і KAI-1. KAI-1 є відомим метастатичним геном-супресором, локалізованим у людини на хромосомі 11p11.2, який спочатку був ідентифікований у пухлинах передміхурової залози. Експресію KAI-1 пригнічено в прогресуючій РТС із метастазами в лімфатичних вузлах і в її анапластичній трансформації [34].

Використання моноклональних антитіл для дослідження NM23-H1 у пацієнтів із фолікулярною карциномою показало вірогідний зворотний зв'язок між метастазуванням та експресією продукту NM23-H1. Імунореактивність білка NM23-H1 зворотно пов'язано з метастатичним потенціалом пухлин і смертністю пацієнтів із FTC. Виявили також, що кількість NM23-H1 у метастатичній тканині лімфатичних вузлів є нижчою, ніж у первинній пухлині диференційованого раку Щ3 [34]. Метастин (кісспептин - продукт гена $K i S S$-1) описано як інгібітор метастазів у лініях клітин меланоми та карциноми молочної залози. Показано, що GPR54 (heptahelical G protein-coupled receptor), рецептор кісспептину, надекспресується в РТC, але зрідка експресується в FTC, оскільки папілярний рак ЩЗ із меншою частотою розвиває віддалені метастази, ніж фолікулярний [34].

\section{Вплив мікрооточення пухлини}

Необхідно відзначити вплив мікрооточення (ніші) пухлини, що визначає її утворення та, надто, розвиток. Накопичується дедалі більше даних щодо ролі стромального мікросередовища, яке впливає на розвиток пухлинних клітин, визначає різні стадії прогресування раку, у тому числі метастазування пухлинних клітин і регуляцію поведінки трансформованих клітин [34]. Незважаючи на те, що пухлинні клітини є джерелом метастазування, нові дані свідчать, що нормальні клітини організму в межах мікрооточення пухлини також відіграють критичну роль у зміні метастатичної поведінки [39]. Вплив мікросередовища опосередковується головним чином через двоспрямовані взаємодії між епітеліальними пухлинними клітинами та сусідніми клітинами строми - ендотеліальними та імунними [34]. Взаємодія включає адгезію, протеоліз, міграцію, механізми захисту від імунної системи, лімфо-/ангіогенезу, виживання та хомінгу до органів-мішеней.

Інфільтрація лімфоцитів зазвичай спостерігається в РТC, надто з RET/РTC-перебудовами. Запалення пов'язано з розвитком і прогнозом PTC [40]. Припускають, що на розмір пухлини та локальне метастазування впливають конкретні види інфільтрованих лімфоцитів [41].

Поодинокі ракові клітини або невеликі кластери ракових клітин можуть виділяти екзосоми та мікровезикули, модифікуючи сусідні тканини для посилення адгезії пухлинних клітин [39]. Пухлина секретує великі мікровезикули, що походять із плазматичної мембрани, які несуть матриксні металопротеїнази. Мікровезикули можуть допомагати міграції пухлинних клітин у межах солідної тканини [42]. Екзосоми, що несуть білки, ліпіди та РНК, опосередковують міжклітинну комунікацію різних типів клітин і функціонують у фізіологічному стані та на тлі патології [42]. Пухлинні екзосоми можуть брати участь у метастатичній дисемінації пухлинних клітин шляхом модифікації клітин-попередників кісткового мозку та сприяння їх міграції в ділянки майбутніх метастазів шляхом безпосереднього посіву в лімфатичних вузлах, що дренують пухлину перед міграцією самих пухлинних клітин, або шляхом посилення локальної мобільності пухлинних клітин за до- 
помогою комплексної взаємодії з оточуючими фібробластами. Екзосоми 3 культивованих пухлинних клітин гліобластоми містять кілька ангіогенних пептидів і РНК, які можуть бути перенесеними та трансльованими в реципієнтах - ендотеліальних клітинах мікросудин мозку. Екзосоми також можуть посилювати ангіогенез, а потім - поширення злоякісної пухлини [43, 44].

Можлива участь мікрооточення в канцерогенезі ЩЗ грунтується на спостереженнях, за якими хронічний автоімунний тиреоїдит (AIT) часто супроводжується злоякісною трансформацією тканини ЩЗ. Тобто, РТС ліпше розвивається у випадку співіснування в залозі клітин з онкогенними мутаціями й AIT. Порушення тканинного гомеостазу через хронічне запалення може створити умови для проліферації клітин, які мають спонтанну RET/PTCперебудову [40]. Тут важливо відзначити роль $\mathrm{NF}-\kappa \mathrm{B}$, ефекти якого пов'язано з гальмуванням апоптозу, активацією проліферації клітин, прогресією пухлин, їх інвазійністю, а також стійкістю до опромінення та хіміотерапії. Важливо також відзначити, що опромінення активує сигнальний каскад NF-кB [8], а отже, й захисні системи пухлинної клітини. У карциномах ЩЗ спостерігається конститутивна активація NFкВ і значно збільшується кількість мРНК і білка субодиниці чинника - p65 порівняно з такою в нормальних клітинах, що підтверджує участь NF-кB у генезі раку Щ3 [45, 46]. RET/PTCперебудови, а також мутації B-Raf i Ras ініціюють МАРК-каскад, який, у свою чергу, призводить до активації NF-кB та опосередкованих онкогенами прогресії й агресивної поведінки PTC $[14,47]$. Показано також, що в клітинах папілярного раку Щ3 людини мутація B-RafV600E активує не лише MAPК, але й сигнальний шлях NF-кB, який спричиняє стійкість до апоптозу та посилення інвазійного потенціалу клітин [48]. Встановлено зворотний зв'язок між NF-кB i Raf - пригнічення активності чинника специфічними інгібіторами інактивує Raf [49]. Є дані, що RET/РTC3-перебудова може також активувати канонічний шлях NF-кB через стабілізацію NF-кB-індукуючої кінази (NIK) у PTC [50]. Злиття генів PAX8-PPAR $\gamma$ унаслідок хромосомної транслокації призводить до втрати здатності PPAR $\gamma$ пригнічувати активацію NF-кB і визначає активацію цикліну D1, який репресує проапоптотичні чинники [45] й ініціює старт клітинного циклу. Генетичне тло $R E T /$ РTC3 пов'язано із секрецією прозапальних медіаторів, у тому числі GM-CSF і MCP-1, контрольованих NF-кB, і пригнічує вроджений імунітет проти раку. Запальний процес хронічно активує NF-кB, що у свою чергу, стимулює експресію цитокінів, хемокінів, чинників росту та каскадів протеаз, що веде до ініціації, прогресування пухлин і забезпечує нішу для злоякісної трансформації. Вважається, що каскад NF-кB є перспективною терапевтичною мішенню в лікуванні раку Щ3 [45].

Епігенетичні зміни в карциномах щитоподібної залози

Крім відомих генетичних змін, пов’язаних із розвитком раку ЩЗ, низка генів змінюють рівень експресії, що не пов’язано з мутаціями, перебудовами або ампліфікаціями, а є результатом порушення епігенетичної регуляції. Такі порушення можуть бути прогностичними маркерами, а в деяких випадках гени використовували як біомаркери злоякісності. До них належать: CITED1, LGAL S3, що кодує галектин-3, а також гени, що кодують високомолекулярні цитокератини та CK19, CD44V6, CD57 і білок невідомої структури та функції, який розпізнається антитілом НВМЕ-1 [51]. Низка досліджень показали, що підвищена регуляція цих біомаркерів і зниження рівня регуляції CD56 можна використовувати, аби розрізнити злоякісні та доброякісні пухлини $[51,52]$. Крім того, профілі таких біомаркерів мають прогностичну цінність, оскільки деякі із цих змін, такі як експресія НBME-1, CK19 і галектину-3, передбачають агресивність карциноми та утворення метастазів [53].

Регулятори клітинного циклу, які епігенетично модифікуються в пухлинах Щ3, також мають прогностичну цінність. Експресія p27 знижується в РТС із метастазами в лімфатичних вузлах, а цикліну D1 - підвищується в цих пухлинах без ознак ампліфікації гена [53]. Експресія р27 частково залежить від PTEN-опосередкованої деградації регулятора циклу, протоонкогена Skp2, яка інгібується вітаміном D [54].

Фібронектин - ще один біомаркер, ідентифікований у ранніх дослідженнях профілів експресії генів у пухлинах ЩЗ, він може свідчити про можливість локальних інвазій. 
Він епігенетично контролюється PTEN і може бути модульований вітаміном D i MAGE-A, який також експресується в агресивніших пухлинах. Експресія фібронектину апрегулюється в інвазійних та агресивних видах раку Щ3, але ефект його дії ще не визначено. Так, є дані, що фібронектин посилює проліферацію та інвазію клітин, але інші дослідження показали, що фібронектин підвищує адгезію та знижує проліферацію [55]. Можливо, епігенетична апрегуляція є компенсаторним явищем, реакцією на модуляцію фібронектином прогресії пухлини.

Іншим геном, експресія якого змінюється в карциномах Щ3, є CEACAM1. Продукт цього гена має ознаки, що вказують на його можливі онкогенні або онкосупресивні функції. У пухлинах ЩЗ експресія білка СЕАСАМ1 визначається в невеликих папілярних карциномах із залученням лімфатичних вузлів, і було показано, що він посилює інвазійність, але гальмує проліферацію. СЕАСАМ1 також є мішенню вітаміну $\mathrm{D}$, що пригнічує його експресію та дію як ефектора інвазійності, але не проліферації, яка опосередковується рецепторами IGF-1 та інсуліну. Остеопонтин, який, як вважають, залучений до дії CD44v6 і CEACAM1, також апрегулюється в агресивних РТС [56]. Встановлено також потенційне прогностичне значення експресії ER $\beta$ у класичних PTC. Надекспресія ER $\beta$ у РTC корелює 3 екстратиреоїдним поширенням і метастазуванням у лімфатичні вузли. Чинники, що регулюють це, не визначено, але є дані, що агресивнішою поведінка раку Щ3 є під час вагітності, водночас відзначено агресивнішу клінічну поведінку DTC у чоловіків порівняно з такою в жінок [53].

Метилювання ДНК $\boldsymbol{i}$ білків. Порушення метилювання генів є епігенетичною ознакою злоякісних пухлин людини, у тому числі й пухлин ЩЗ. Метилювання, як правило, інгібує ген, коли відбувається в ділянці промотора. Встановлено, що мутацію B-Raf V600E пов'язано з гіперметилюванням кількох генів пухлинних супресорів, включаючи ТIMP3 (тканинний інгібітор металопротеїназ 3), SLC5A8, DAPK1 (death-associated protein kinase 1) i RARB (retinoic acid receptor- $\beta$ ) 70 . Мікроерей-дослідження метилювання ДНК у клітинах РТС виявило широке гіперметилю- ванням генів по всьому геному, яке керується сигналінгом B-Raf V600E. У цій же праці виявили в геномі велику кількість гіпометильованих генів, що призводить до їх надекспресії й також контролюється B-Raf V600Е. Гіперметильовані або гіпометильовані гени відіграють важливу роль у метаболізмі та функціонуванні клітин. Отже, зміни в метилюванні генів, поєднані з B-Raf V600Е та, імовірно, з іншими онкопротеїнами, є важливим епігенетичним механізмом у канцерогенезі Щ3 [14, 57].

Метилювання промотора PTEN часто спостерігається в FTC та АTC, що призводить до зупинки експресії PTEN. Метилювання PTEN пов'язано з генетичними змінами шляху PI3K/ Akt у пухлинах Щ3, включаючи мутації різних ізоформ Ras, мутації та ампліфікації PIK3CA та мутації PTEN [57]. Це узгоджується з моделлю, за якою аберантна активація шляху PI3K/ Akt, зумовлена активуючими генетичними змінами, викликає порушення метилювання, а отже, «мовчання» гена PTEN, що, у свою чергу, призводить до неспроможності гальмувати передачу сигналу PI3K/Akt, створюючи петлю позитивного зворотного зв’язку, яка підсилює активність цього каскаду [57].

RasAL1, білок, що активує GTРазу Ras (RasGAP), було виявлено як основний пухлинний супресор у пухлинах Щ3. RasGAP активує внутрішню GTPaзy Ras, яка гідролізує GTP, перетворюючи активний GTP-зв'язаний Ras на неактивний GDP-зв'язаний Ras, що припиняє передачу сигналу Ras. Вважалося, що мутації Ras - єдиний генетичний механізм активації Ras у пухлинах ЩЗ. Дослідження, що виявили генетичні та епігенетичні зміни, які інактивують RasAL1, визначили новий важливий генетичний механізм активації Ras. Виявлено, що серед великої кількості досліджених генів RasGAP лише RasAL1 цілком метильовано та пригнічено в клітинах раку Щ3, що свідчить про унікальну та надто важливу роль цього гена в канцерогенезі Щ3 [58]. Rap1 (Ras-proximate-1, або Ras-related protein1) іншою GTРазою, яка діє як онкоген, подібно до Ras. Вiн регулюється Rap1 GTPaзаактивуючим білком - Rap1GAP. Цей інгібуючий ген пригнічено в РТС, але статус метилювання цього гена невідомий. Метилювання супресора Ras - RasSF1A свідчить про зміни на епігенетичному рівні та є найбільш раннім 
Огляди

проявом патогенетичних процесів у ЩЗ. Метилювання NOR1A й експресія B-Raf характеризує РТС й АТС [59].

Інший ген, який апрегулюється в пухлинах Щ3 через гіпометилювання промотоpa, - SERPINB5, кодує білок родини серпінів (serine protease inhibitor) - маспін (mammary serine protease inhibitor), пухлинний супресор. Він відносно зрідка виявляється в диференційованих раках ЩЗ, є більш характерною рисою для процесу дедиференціації, що є досить дивним для пухлинних супресорів. Подібно до фібронектину, парадоксальна регуляція цього гена може відображати компенсаторну відповідь. Інші онкогенні чинники, які регулюються метилюванням, включають INSL4, що належить до сімейства інсуліну/IGF; DPPA2, ген плюрипотентності; TCL1B і NOTCH4 [60].

Метилювання ДНК, що пригнічує транскрипцію генів, є поширеною подією. За ракових захворювань переважно гальмується експресія генів пухлинних супресорів. У пухлинах ЩЗ метилювання ДНК ідентифіковано в поєднанні зі зниженням експресії генівсупресорів пухлин, а також специфічних для тканин чинників диференціювання. Диференційований рак Щ3 експресує TTF-1 (Thyroid Transcription Factor 1), який кодується геном NKX2-1 (NK2 homeobox 1). Цей ген даун-регулюється метилюванням ДНК, а також модифікацією гістону Н3 у менш диференційованих карциномах Щ3 [61].

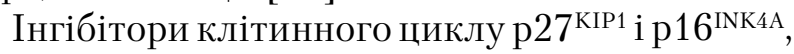
p14 (ARF) i білок ретинобластоми (pRb1) є супресорами пухлин, які даун-регулюються в деяких диференційованих раках ЩЗ. Метилювання промоторів кодуючих їх генів є потенційним чинником, що зумовлює їх знижену регуляцію [62]. Проте рівень р27 головним чином регулюється деградацією білка.

Зародкову мутацію PTEN пов'язано із синдромом хамартоми (у тому числі із синдромами Баннаян - Райлі - Рувалькаба та Коудена), що характеризується новоутвореннями в ЩЗ та іншими пухлинами. Хоча мутації не трапляються в спорадичних пухлинах, описано метилювання ДНК, яке викликає «мовчання» гена $P T E N$ у спорадичних FA, PTC і FTC.

Ген Ras SF1A кодує протеїн, який є гомологічним до ефекторного білка Ras. Він пов'язаний iз модуляцією сигналінгу Ras i пригнічується метилюванням у FA, FTC і FVPTC, які мають мутації Ras або Ras-подібні профілі експресії, але не змінюється в РТС із сигналінгом через шлях B-Raf [54].

DAPK (Death-associated protein kinase) серин/треонінова кіназа, що сприяє апоптозу, індукованому чинником некрозу пухлини, через взаємодію з білком, що зв'язується з убіквітин-лігазою DIP-1 (DAPK-interacting protein). Ген, який кодує цей пухлинний супресор, метилюється в пухлинах ЩЗ і також корелює з їх агресивністю. REC8, специфічний для мейозу ген, пригнічується РI3К шляхом гіперметилювання. Гіперметилювання REC8 пов'язано 3 поганим прогнозом у карциномах ЩЗ, включаючи їх прогресію та смерть пацієнта [63]. Ген, що кодує DACT (Dishevelled-associated antagonist of $\beta$-catenin), інгібітор сигнального каскаду WNT, пригнічується в РТC шляхом метилювання промотора [64]. Тканинний інгібітор металопротеїнази (ТIMP) інгібує інвазійність, ангіогенез і метастазування. Цей ген гіперметильовано в пухлинах ЩЗ, і метилювання корелює 3 агресивністю пухлини. E-кадгерин, кодований геном $C D H 1$, інтенсивно експресується в нормальних фолікулярних клітинах Щ3, тоді як у диференційованих карциномах ЩЗ зниження експресії цієї молекули адгезії провокує агресивну поведінку пухлин. «Мовчання» гена Е-кадгерину через метилювання промотора - важливий механізм для цієї даун-регуляції. FGFR є супресором пухлин та епігенетично пригнічується в пухлинах ЩЗ через метилювання острівців CpG. Підвищення регуляції цього гена призводить до пригнічення сигналінгу B-Raf, що знижує інвазійність клітин раку ЩЗ. Інші гени, «мовчання» яких пов'язано 3 дерегуляцією метилюванням у пухлинах ЩЗ, включають потенційні гени супресорів пухлини $A D A M T S 8$, HOXB4, ZIC1 i KISS1R, а також HIST1H3J, POU4F2, SHOX2, PHKG2, TLX3, HOXA7 і гени, що кодують WT1 (Wilms tumor 1) [60, 65]. Дослідження в мережі TCGA (The Cancer Genome Atlas) визначили, що Ras-подібні пухлини мають низький рівень білків фібронектину, VHL, CHK2 і високу експресію білків клаудіну-7, TIGAR і BRCA2 [13]. Пухлини розділено на два кластери метилювання: один типовий для нормальної ЩЗ, а інший характеризується гіперметилюванням острівців CpG. 
B-Raf-подібні пухлини також розділено на два кластери метилювання з однією групою, яку класифіковано як висококлітиноподібну, що включає більшу частину висококлітинних варіантів пухлин. Ця група мала найнижчу диференціацію Щ3 і була пов'язаною з більш розвиненою стадією пухлини та підвищеним ризиком, а також практично цілком перекривалась специфічним патерном експресії мікроРНК [54].

Зміни експресії мікроРНК у пухлинах Щ3. МікроРНК - короткі некодуючі РНК, 19-23 нуклеотидів, які опосередковують «мовчання» генів на посттранскрипційному рівні за рахунок деградації таргетних мРНК або блокування трансляції. Кожна мікроРНК може мати кілька мішеней, 3 якими вона зв’язується за допомогою компліментарних послідовностей. Функціонуючи як онкогени або пухлинні супресори, мікроРНК впливають на онкогенез, оскільки беруть участь у регуляції багатьох генів, залучених до малігнізації тканин [66]. У декількох працях аналізували експресію мікроРНК у пухлинах ЩЗ та оцінювали їх можливу роль у процесі канцерогенезу. Багато мікроРНК було ідентифіковано як дерегульовані в неоплазіях Щ3 [67]. Дослідження (із залученням понад 800 пацієнтів) [68] рівня експресії мікроРНК-21, -34b, $-130 \mathrm{~b},-135 \mathrm{~b},-146 \mathrm{~b},-151,-181 \mathrm{~b},-199 \mathrm{~b}-5 \mathrm{p},-221$, $-222,-22451,-623,-1271,-2861$ i let-7е виявили вірогідну асоціацію з принаймні однією рисою агресивної поведінки пухлин, що не включала мутації B-Raf V600E, яка зараз не вважається визнаним показником агресивності [69]. Найбільш диференційно експресуються в РТС мікроРНК-146b, -221, -187, -30d i -155, рівень яких підвищується [70]. Порівняльний аналіз біопсійних зразків від двадцяти пацієнтів із РТС показав 95\% чутливість мікроРНК-221 у виявленні РТС [71]. Це підтверджується іншими даними про підвищення регуляції мікроРНК-146b і мікроРНК-221/222 у диференційованих раках Щ3 [72]. Обидва сімейства мікроРНК регулюються NFкB [67], що свідчить про участь цього чинника в патогенезі раку ЩЗ. Кластер мікроРНК-221/222 на $\mathrm{X}$-хромосомі відомий як регулятор клітинного циклу та апоптозу в руслі МАРК-каскаду, включаючи пригнічення р27. Іншою мішенню є TIMP3 [72]. Рівні мікроРНК-221/222 було пов'язано зі стійкістю до лікування, рецидивами, гіршим прогнозом та агресивністю новоутворень [67]. Сімейство мікроРНК-146а/b бере участь у кровотворенні, імуномодуляції та запаленні. Ці гомологічні мікроРНК, що кодуються на хромосомах 5 і 10 відповідно, також регулюють клітинний цикл, апоптоз та ЕMT у різних злоякісних новоутвореннях. Рівень мікроРНК-146 не змінюється в доброякісних пухлинах ЩЗ, але зростає в РТС, FVPTC i FTC [73]. МікроРНК-146b пригнічує рецептор тиреоїдного гормону бета-23 (THRB), SMAD4, ZNFR3 та IRAK1 (IL-1 receptor-associated kinase 1), посилюючи проліферацію, інвазійність та ЕМТ [72, 74, 75]. У більшості праць їі визначено як предиктор агресивності пухлин, і за її експресією можна розрізняти агресивні B-Raf V600E мутантні РТС від неагресивних. Роль мікроРНК-146b у регуляції експресії рецептора ретиноєвої кислоти (RAR)- $\beta$, Pax8 i NIS $[76,77]$ дає нове розуміння механізмів дедиференціації раку Щ3. МікроРНК-155, рівень якої підвищується в РТС, має своєю мішенню АРС і пригнічує сигналінг WNT/бета-катенін [78]. МікроРНК, рівень яких знижується в агресивних пухлинах, включають мікроРНК-1, -16, -21, -34b, -130b, -613. Виявлено, що мікроРНК-34b i мікроРНК-1 націлено на Met, і зниження їх вмісту пов'язано з більшими рівнями експресії білка Met, які спостерігаються в агресивних РТC. Даун-регуляцію мікроРНК-16 і мікроРНК-613 пов'язано зі зміненою експресією ITAG2 і FN1 у більш агресивних РТC [72]. Зниження рівня мікроРНК-21 у РТС призводить до пригнічення PTEN, а також THRB може діяти через зміни експресії супресора пухлини PDCD4 (Programmed cell death protein 4) [67, 79]. МікроРНК-181 може функціонувати і як онкоген, і як пухлинний супресор через ще невідомі механізми. МікроРНК let-7 є пухлинним супресором, мішенню якого є шлях МАРК у багатьох пухлинах, включаючи карциноми ЩЗ. Цікаво, що let-7 також залучено до регуляції мікроРНК-181 [67]. Суттєве зниження експресії мікроРНК-30d, -125b, -26a, -30a-5p порівняно з нормальною тканиною є характерною ознакою АТС [80], що, напевно, відіграє важливу роль у трансформації клітин ЩЗ.

Одинадцять мікроРНК ідентифіковано як маркери інвазійності та метастазування 


\section{Огляди}

PТC. МікроРНК-146b суттєво надекспресовано в РТС з екстратиреоїдними інвазіями та пов'язано з пухлинами високого ризику 3 мутацією B-Raf. Експресія мікроРНК-146b $\epsilon$ незалежним чинником ризику для поганого прогнозу в РТС разом із цервікальними метастазами в лімфатичних вузлах.

Отже, визначення дерегульованих мікроРНК може мати прогностичне значення в РТС, але це потребує додаткових досліджень.

\section{Висновки}

Знання тонких біохімічних механізмів, що призводять до малігнізації тканини ЩЗ, дає можливість розробляти нові підходи до лікування неоперабельних і стійких до радіойоду форм раку.

1. Пошук ефективних інгібіторів рецепторних

і вільних цитоплазматичних тирозинкіназ

i пов'язаних із ними сигнальних каскадів - це один із перспективних напрямів, пов'язаний із визначенням можливостей пригнічення або інактивації білка Ras, який у багатьох випадках є ключовим чинником, що визначає трансформацію клітини. Насамперед це інгібітори фарнезилтрансферази (мануміцин A) - ферменту, який бере участь в іммобілізації Ras на мембранах, що приводить до активації цього чинника. Вже одержані та використовуються в передклінічних дослідженнях інгібітори Raf-кіназ та ERK.

2. Іншим важливим напрямом є пошук та вдосконалення блокаторів клітинного циклу таких, як, наприклад, інгібітор циклін-залежних кіназ росковітин, а також сполук, що пригнічують синтез ДНК.

3. Перспективним є пригнічення метастазування та ангіогенезу з використанням інгібіторів рецепторів ростового чинника ендотелію судин та інших ростових чинників.

4. Необхідні подальші дослідження відомих i розробка нових інгібіторів сигнального каскаду PI3K - PDK, Akt, mTOR, p70S6K.

5. Актуальним є пошук і застосування ефективних інгібіторів: метилювання ДНК (decitabine), деацетилази гістонів (вальпроєва кислота), топоізомерази (irinotecan), циклооксигенази-2 (celecoxib), білків теплового шоку та протеосом (bortezomib).
6. Дає обнадійливі результати використання протипухлинних сполук загальної дії: антимітотичних сполук (таксани) та сполук, що пошкоджують ДНК (цисплатин, іонізуюча радіація). Значна кількість вказаних вище інгібіторів вже використовується зараз або проходить II і III стадії клінічних досліджень, і це, разом із традиційними методами лікування раку ЩЗ, має дати позитивні результати щодо терапії як диференційованих карцином, так i, надто, анапластичного раку та МТC.

Подальші дослідження, що використовують весь арсенал сучасних методів молекулярної генетики та біології, дозволять розширити спектр біологічних маркерів канцерогенезу Щ3, з'ясувати тонкі механізми радіаційного впливу на тканину залози та закласти фундамент для розробки нових методів таргетної терапії.

\section{Список використаної літератури}

1. Lodish MB, Stratakis CA. RET oncogene in MEN2, MEN2B, MTC and other forms of thyroid cancer. Expert Rev Anticancer Ther. 2008;8:625-32.

2. Wohllk N, Schweizer H, Erlic Z, Schmid KW, Walz MK, Raue F, et al. Multiple endocrine neoplasia type 2. Best Pract Res. Clin Endocrinol Metab. 2010;24:371-87.

3. Romei C, Ciampi R, Elisei R. A comprehensive overview of the role of the RET proto-oncogene in thyroid carcinoma. Nat Rev Endocrinol. 2016; 12(4):192-202.

4. Roman S, Mehta P. Sosa JA. Medullary thyroid cancer: early detection and noveltreatments. Curr Opin Oncol. 2009;21(1):5-10.

5. Abu-Amero KK, AlzahraniAS, Zou1 M, Shi Y. Association of mitochondrial DNA transversion mutations with familial medullary thyroid carcinoma/multiple endocrine neoplasia type 2 syndrome. Oncogene. 2006;25:677-84.

6. Van Veelen W, Klompmaker R, Gloerich M, van Gasteren CJ, Kalkhoven E, Berger R, et al. P18 is a tumor suppressor gene involved in human medullary thyroid carcinoma and pheochromocytoma development. Int J Cancer. 2009;124(2):339-45.

7. PushkarevVM, Kovzun OI, Tronko MD. Molecular-genetic mechanisms of malignant thyroid tumors formation.J AMN Ukraine. 2009;15(1):116-27.

8. Pushkarev VM, Kovzun OI, Pushkarev VV, Guda BB, Tronko MD. Biochemical aspects of the combined use of taxanes, irradiation and other antineoplastic agents for the treatment of anaplastic thyroid carcinoma. Ukr Biochem J. 2018;90(5):5-19.

9. Pstrag N, Ziemnicka K, Bluyssenand H, Wesoly J. Thyroid cancers of follicular origin in a genomic light: in-depth overview of common and unique molecular marker candidates. Mol Cancer. 2018;17:116.

10. Smallridge R, Marlow L, Copland J. Anaplastic thyroid cancer: molecular pathogenesis and emerging therapies. Endocr Relat Cancer. 2009;16(1):17-44.

11. Molinaro E, Romei C, Biagini A, Sabini E, Agate L, Mazzeo S, et al. Anaplastic thyroid carcinoma: from clinicopathology to genetics and advanced therapies. Nat Rev Endocrinol. 2017;13(11):644-60.

12. Tronko ND, Pushkarev VM. Thirty years after the Chernobyl accident: Molecular genetic mechanisms of carcinogenesis of the thyroid gland. Cytol Genet. 2016;50(6):366-71.

13. Agrawal N, Akbani R, Aksoy BA, Ally A, Arachchi H, Asa SL, et al. Integrated genomic characterization of papillary thyroid carcinoma. Cell. 2014;159(3):676-90. 
14. Xing M. Molecular pathogenesis and mechanisms of thyroid cancer. Nat Rev Cancer. 2013;13(3):184-99.

15. Charles RP, Silva J, Iezza G, PhillipsWA, McMahon M. Activating BRAF and PIK3CA mutations cooperate to promote anaplastic thyroid carcinogenesis. Mol Cancer Res. 2014;12(7):979-86.

16. Takano T. Fetal cell carcinogenesis of the thyroid: a modified theory based on recent evidence. Endocr J. 2014;61(4):311-20.

17. Guo Z, Hardin H, Lloyd RV. Cancer stem-like cells and thyroid cancer. Endocr Relat Cancer. 2014;21(5):285-300.

18. Hardin H, Zhang R, Helein H, Buehler D, Guo Z, Lloyd RV. The evolving concept of cancer stem-like cells in thyroid cancer and other solid tumors. Lab Invest. 2017;97(10):1142-51.

19. Kunstman JW, Juhlin CC, Goh G, Brown TC, Stenman A, Healy JM, et al. Characterization of the mutational landscape of anaplastic thyroid cancer via whole-exome sequencing. Hum Mol Genet. 2015;24(8):2318-29.

20. Xu B, Ghossein R. Genomic landscape of poorly differentiated and anaplastic thyroid carcinoma. Endocr Pathol. 2016;27(3):205-12.

21. Landa I, Ibrahimpasic T, Boucai L, Sinha R, Knauf JA, Shah RH, et al. Genomic and transcriptomic hallmarks of poorly differentiated and anaplastic thyroid cancers. J Clin Invest. 2016;126(3):1052-66.

22. Pallante $\mathrm{P}$, Federico A, BerlingieriMT, Bianco M, Ferraro A Forzati F, et al. Loss of the CBX7 Gene expression correlates with a highly malignant phenotype in thyroid cancer. Cancer Res. 2008;68(16):6770-8.

23. Montero-Conde C, Martin-Campos JM, Lerma E, Gimenez G, Martínez-Guitarte JL, Combalía N, et al. Molecular profiling related to poor prognosis in thyroid carcinoma. Combining gene expression data and biological information.Oncogene. 2008;27(11):1554-61

24. Pushkarev VM, Starenki DV, Saenko VO, Tronko MD, Yamashita S. Effects of Paclitaxel and combination of the drug with radiation therapy in an in vivo model of anaplastic thyroid carcinoma. Exp. Oncol. 2011;33(1):24-7.

25. Pushkarev VM, Kovzun OI, Pushkarev VV, Tronko MD. Biochemical effects of combined action of $\gamma$-irradiation and paclitaxel on anaplastic thyroid cancer cells. Ukr Biokhim Zh. 2013;85(1):51-61.

26. Pushkarev VM, Starenki DV, Saenko VA, Namba H, Kurebayashi J, Tronko MD, Yamashita S. Molecular mechanisms of the effects of low concentrations of taxol in anaplastic thyroid cancer cells Endocrinology. 2004;147(7):3143-52.

27. Pushkarev VM, Starenki DV, Saenko VA, Pushkarev VV, Kovzun OI Tronko MD, Popadiuk ID, Yamashita S. Differential effects of low and high doses of taxol in anaplastic thyroid cancer cells: possible implication of the Pin1 prolyl isomerase. Exp. Oncol. 2008;30(3):190-4

28. Pushkarev VM, Starenki DV, Saenko VA, Yamashita S, Kovzun OI, Popadiuk ID, Pushkarev VV, Tronko MD. Effects of low and high concentrations of antitumour drug taxol in anaplastic thyroid cancer cells. Exp. Oncol. 2009;31(1):16-21.

29. Pushkarev VV, Kovzun OI, Pushkarev VM, Tronko MD. The effect of the combined action of roscovitine and paclitaxel on the apoptotic and cell cycle regulatory mechanisms in colon and anaplastic thyroid cancer cells. ISRN Biochemistry. 2012;2012(826305):1-6.

30. Gild ML, Bullock M, Robinson BG, Clifton-Bligh R. Multikinase inhibitors: a new option for the treatment of thyroid cancer. Nat Rev Endocrinol. 2011;7(10):617-24.

31. Tsuji T, Ibaragi S, Hu GF. Epithelial-mesenchymal transition and cell cooperativity in metastasis. Cancer Res. 2009;69(18):7135-9.

32. Huber MA, Kraut N, Beug $\mathrm{H}$. Molecular requirements for epithelial-mesenchymal transition during tumor progression. Curr Opin Cell Biol. 2005;17(5):548-58.

33. Zhang Z, Liu ZB, Ren WM, Ye XG, Zhang YY. The miR-200 family regulates the epithelial-mesenchymal transition induced by EGF/EGFR in anaplastic thyroid cancer cells. Int J Mol Med. 2012;30(4):856-62.

34. Xie J, Fan Y, Zhang X. Molecular mechanisms in differentiated thyroid cancer. Front Biosci Landmark. 2016;21:119-29.

35. Torregrossa L, Giannini R, Borrelli N, Sensi E, Melillo RM, Leocata P, et al. CXCR4 expression correlates with the degree of tumor infiltration and BRAF status in papillary thyroid carcinomas. Mod Patho. 2012;25(1):46-55

36. Tan A, Xia N, Gao F, Mo Z, Cao Y. Angiogenesis-inhibitors for metastatic thyroid cancer. Cochrane Database Syst Rev. 2010;3: CD007958.
37. Ferrari SM, Fallahi P, Ruffilli I, Elia G, Ragusa F, Paparo SR, et al. Molecular testing in the diagnosis of differentiated thyroid carcinomas. Gland Surg. 2018;7(Suppl 1):S19-29.

38. Horak CE, Lee JH, Marshall JC, Shreeve SM, Steeg PS. The role of metastasis suppressor genes in metastatic dormancy. APMIS. 2008;116(7-8):586-601.

39. Peinado H, Lavotshkin S, Lyden D. The secreted factors responsible for pre-metastatic niche formation: old sayings and new thoughts. Semin Cancer Biol. 2011;21(2):139-46.

40. Guarino V, Castellone MD, Avilla E, Melillo RM. Thyroid cancer and inflammation. Mol Cell Endocrinol. 2010;321(1):94-102.

41. French JD, Weber ZJ, Fretwell DL, Said S, Klopper JP, Haugen BR. Tumor-associated lymphocytes and increased FoxP3+ regulatory $\mathrm{T}$ cell frequency correlate with more aggressive papillary thyroid cancer. J Clin Endocrinol Metab. 2010;95(5):2325-33

42. Colombo M, Raposo G, Thery C. Biogenesis, secretion, and intercellular interactions of exosomes and other extracellular vesicles. Annu Rev Cell Dev Biol. 2014;30:255-89.

43. Hood JL, San RS, Wickline SA. Exosomes released by melanoma cells prepare sentinel lymph nodes for tumor metastasis. Cancer Res. 2011;71(11):3792-801

44. Luga V, Zhang L, Viloria-Petit AM, Ogunjimi AA, Inanlou MR Exosomes mediate stromal mobilization of autocrine Wnt-PCP signaling in breast cancer cell migration. Cell. 2012;151(7):1542-56

45. Li X, Abdel-Mageed AB, Mondal D, Kandil E. The nuclear factor kappa-B signalling pathway as a therapeutic target against thyroid cancers. Thyroid. 2013;23(2):209-18.

46. Giuliani C, Bucci I, Napolitano G. The role of the transcription factor Nuclear Factor-kappa B in thyroid autoimmunity and cancer. Front Endocrinol. 2018;9:471

47. Spitschak A, Meier C, Kowtharapu B, Engelmann D, Pützer BM. MiR-182 promotes cancer invasion by linking RET oncogene activated NF- $\mathrm{KB}$ to loss of the HES1/Notch1 regulatory circuit. Mol Cancer. 2017;16(1):24.

48. Palona I, Namba H, Mitsutake N, Starenki D, Podtcheko A, Sedliarou I, et al. BRAFV600E promotes invasiveness of thyroid cancer cells through nuclear factor kappaB activation. Endocrinology. 2006;147(12):5699-707.

49. Pushkarev VV, Starenki DV, Pushkarev VM, Kovzun OI, Tronko MD. Inhibitor of the transcription factor NF- $\kappa B$, DHMEQ enhances the effect of paclitaxel on cells of anaplastic thyroid carcinoma in vitro and in vivo. Ukr Biochem J.2015;87(3):33-44.

50. Neely RJ, Brose MS, Gray CM, McCorkell KA, Leibowitz JM $\mathrm{Ma} C$, et al. The RET/PTC3 oncogene activates classical NF- $\kappa \mathrm{B}$ by stabilizing NIK.Oncogene. 2011;30(1):87-96.

51. Prasad ML, PellegataNS, Huang Y, Nagaraja HN, de la Chapelle A, Kloos RT. Galectin-3, fibronectin-1, CITED-1, HBME1 and cytokeratin-19 immunohistochemistry is useful for the differential diagnosis of thyroid tumors. Mod Pathol. 2005;18(1):48-57.

52. Dunderovic D, Lipkovski JM, Boricic I, Soldatovic I, Bozic V, Cvejic D, et al. Defining the value of CD56, CK19, Galectin 3 and HBME-1 in diagnosis of follicular cell derived lesions of thyroid with systematic review of literature. Diagn. Pathol. 2015;10:196

53. Cheng S, Liu W, Mercado M, Ezzat S. Asa SL. Expression of the melanoma-associated antigen is associated with progression of human thyroid cancer. EndocrRelat Cancer. 2009;16(2):455-66.

54. Asa SL, Ezzat S. The epigenetic landscape of differentiated thyroid cancer. Mol Cell Endocrinol. 2018;469:3-10.

55. Sponziello M, Rosignolo F, Celano M, Maggisano V, Pecce V, De Rose RF, et al. Fibronectin-1 expression is increased in aggressive thyroid cancer and favors the migration and invasion of cancer cells. Mol Cell Endocrinol. 2016;431:123-32.

56. Liu W, Guo M, Ezzat S, Asa SL. Vitamin D inhibits CEACAM1 to promote insulin/IGF-I receptor signaling without compromising anti-proliferative action. Lab Invest. 2011;91(1):147-56.

57. Hou P, Ji M, Xing M. Association of PTEN gene methylation with genetic alterations in the phosphatidylinositol 3-kinase/ AKT signaling pathway in thyroid tumors. Cancer. 2008; 113(9):2440-7.

58. Xing M. RASAL1 in thyroid cancer: promise from a new friend. J Clin Endocrinol Metab. 2014;99(10):3619-21.

59. Nakamura N, Carney JA, Jin L. RASSF1A and NORE1A methylation and BRAFV600E mutations in thyroid tumors. Lab Invest. 2005;85(9):1065-75. 


\section{Огляди}

60. Rodriguez-Rodero S, Fernandez AF, Fernandez-Morera JL, Castro-Santos P, Bayon GF, Ferrero C, et al. DNA methylation signatures identify biologically distinct thyroid cancer subtypes. J Clin Endocrinol Metab. 2013;98(7):2811-21

61. Kondo T, Nakazawa T, Ma D, Niu D, Mochizuki K, Kawasaki T, et al. Epigenetic silencing of TTF-1/NKX2-1 through DNA hypermethylation and histone $\mathrm{H} 3$ modulation in thyroid carcinomas. Lab Invest. 2009;89(7):791-9.

62. Ishida E, Nakamura M, Shimada K, Higuchi T, Takatsu K, Yane K, https://www.ncbi.nlm.nih.gov/pubmed/?term=Ishida\%20E\%5B Author\%5D\&cauthor=true\&cauthor_uid=12149142 Shimada K. DNA hypermethylation status of multiple genes in papillary thyroid carcinomas. Pathobiology.2007;74(6):344-52.

63. Liu D, Shen X, Zhu G, Xing M. REC8 is a novel tumor suppressor gene epigenetically robustly targeted by the PI3K pathway in thyroid cancer. Oncotarget. 2015;6(36):39211-24.

64. Zhao Z, Herman JG, Brock MV, Sheng J, Zhang M, Liu B, et al. Methylation of DACT2 promotes papillary thyroid cancer metastasis by activating Wnt signaling. PLoS ONE. 2014;9:e112336.

65. Mancikova V, Buj R, Castelblanco E, Inglada-Perez L, Diez A, de Cubas AA, et al. DNA methylation profiling of well-differentiated thyroid cancer uncovers markers of recurrence free survival. Int J Cancer. 2014;135(3):598-610.

66. Di Leva G, Garofalo M, Croce CM. MicroRNAs in cancer. Annu Rev Pathol. 2014;9:287-314.

67. Pallante P, Battista S, Pierantoni GM, Fusco A. Deregulation of microRNA expression in thyroid neoplasias. Nat Rev Endocrinol. 2014;10(2):88-101.

68. Aragon HP, Weng CH, Khawaja HT, Nagarajan N, Schneider EB Umbricht CB, et al. MicroRNA expression and association with clinicopathologic features in papillary thyroid cancer: a systematic review. Thyroid 2015;25(12):1322-9.

69. Shi X, Liu R, Basolo F, Giannini R, Shen X, Teng D, et al. Differential clinicopathological risk and prognosis of major papillary thyroid cancer variants. J Clin Endocrinol Metab. 2016;101(1):264-74.

70. Zhang $\mathrm{X}$, Mao $\mathrm{H}, \mathrm{Lv} \mathrm{Z}$. MicroRNA role in thyroid cancer pathogenesis. Front Biosci (Landmark Ed). 2013;18:734-9.

71. Mazeh H, Mizrahi I, Halle D, Ilyayev N, Stojadinovic A Development of a microRNA-based molecular assay for the detection of papillary thyroid carcinoma in aspiration biopsy samples. Thyroid. 2011;21(2):111-8.

72. Yang Z, Yuan Z, Fan Y, Deng X, Zheng Q. Integrated analyses of microRNA and mRNA expression profiles in aggressive papillary thyroid carcinoma. Mol Med Rep. 2013;8(5):1353-8.

73. Guo Z, Hardin H, Montemayor-Garcia C, Asioli S, Righi A, Maletta F, et al. In situ hybridization analysis of miR-146b-5p and miR-21 in thyroid nodules: diagnostic implications. Endocrine Pathology. 2015;26(2):157-63.

74. Chou CK, Chi SY, Huang CH, Chou FF, Huang CC, Liu RT, et al. IRAK1, a target of miR-146b, reduces cell aggressiveness of human papillary thyroid carcinoma. J Clin Endocrinol Metab. 2016;101(11):4357-66

75. Lima CR, Geraldo MV, Fuziwara CS, Kimura ET, Santos MF. MiRNA-146b-5p upregulates migration and invasion of different papillary thyroid carcinoma cells. BMC Cancer. 2016;16:108.

76. Czajka AA, Wojcicka A, Kubiak A, Kotlarek M, Bakula-Zalewska E, Koperski L, et al. Family of microRNA-146 regulates RARbeta in papillary thyroid carcinoma. PLoS ONE. 2016;11:e0151968.

77. Riesco-Eizaguirre G, Wert-Lamas L, Perales-Paton J, SastrePerona A, Fernandez LP, Santisteban P. The miR-146b-3p/PAX8 NIS regulatory circuit modulates the differentiation phenotype and function of thyroid cells during carcinogenesis. Cancer Research. 2015;75(19):4119-30.

78. Zhang X, Li M, Zuo K, Li D, Ye M, Ding L, et al. Upregulated miR-155 in papillary thyroid carcinoma promotes tumor growth by targeting APC and activating Wnt/beta-catenin signaling. J Clin Endocrinol Metab. 2013;98(8):E1305-13.
79. Zhang J, Yang Y, Liu Y, Fan Y, Liu Z, Wang X, et al. MicroRNA-21 regulates biological behaviors in papillary thyroid carcinoma by targeting programmed cell death 4. J Surg Res. 2014;189(1):68-74.

80. Visone R, Pallante P, Vecchione A, Cirombella R, Ferracin M, Ferraro A, et al. Specific microRNAs are downregulated in human thyroid anaplastic carcinomas. Oncogene. 2007;26(54):7590-5.

(Надійшла до редакції 06.05.2019р.)

\section{Молекулярно-генетические механизмы патогенеза злокачественных опухолей щитовидной железы (часть 2)}

\section{Б.Б. Гуда, В.М. Пушкарев, А.Е. Коваленко, В.В. Пушкарев, Е.И. Ковзун, Н.Д. Тронько}

ГУ «Институт эндокринологии и обмена веществ им. В.П. Комиссаренко НАМН Украины»

Резюме. В части 2 обзора анализируются новые данные по патогенезу медуллярного и анапластического рака - наиболее агрессивных типов злокачественных опухолей щитовидной железы. Значительное внимание уделяется механизмам эпителиально-мезенхимального перехода и образования метастазов, роли микроокружения опухолей и воспалительных процессов в патогенезе. Сделан также акцент на эпигенетических изменениях, которые приводят к возникновению и прогрессированию опухолей щитовидной железы, в частности метилировании ДНК и гистонов, экспрессии микроРНК.

Ключевые слова: щитовидная железа, медуллярный рак, анапластичний рак, метилирование, микроРНК.

\section{Molecular-genetic mechanisms of the pathogenesis of thyroid malignant tumor (Part 2)}

\section{B.B. Guda, V.M. Pushkarev, A.E. Kovalenko, V.V. Pushkarev, O.I. Kovzun, M.D. Tronko \\ SI «V.P. Komisarenko Institute of Endocrinology and Metabolism, NAMS of Ukraine»}

Abstract. Part 2 of the review analyzes new data on the pathogenesis of medullary and anaplastic cancers, the most aggressive types of thyroid malignant tumors. Considerable attention is paid to the mechanisms of epithelial-mesenchymal transition and the formation of metastases, the role of the microenvironment of tumors and inflammatory processes in the pathogenesis. Emphasis is also placed on epigenetic changes that lead to the generation and progression of thyroid tumors, in particular, DNA and histone methylation, miRNA expression.

Keywords: thyroid gland, medullary cancer, anaplastic cancer, methylation, miRNA. 